\title{
Sufi Literature as an Effective Tool for Harmonization in the World: A Case Study of Sultan-ul-Arifeen Sultan Bahoo
}

\author{
Sultan Ahmed Ali
}

\begin{abstract}
In the contemporary era of globalization, literature is no longer exclusive to one specific region. It has always played a major role in driving cultural values and moral traditions, which have gained even more importance in today's pluralistic and multicultural world. Sufi literature - whether of Arabic, Persian, Turkish, Punjabi or Sindhi origin - is known to focus on a universal message of tolerance and forgiveness, countering the very foundations of the social evils such as radicalization, extremism, xenophobia and Islamophobia that pose a considerable threat to the peaceful co-existence of societies. It puts special emphasis on the transformation of human character by acquainting one with the divine morality. This paper will argue that in the contemporary era of geopolitical uncertainties and turmoil, Sufi literature is a useful source of literature that disseminates message of peace and harmony in societies especially when individuals are being victimized of identity crisis, frustration, extremism and bigotry. By analysing the works of Sultan-ul-Arifeen Sultan Bahoo (d.1691), a renowned Sufi of South Asia, the paper will attempt to justify how his teachings and literature on harmony, unity, and self-awareness has been transforming individuals and societies across the region. Through folklores, folk music and other similar mediums, Punjabi Abyāt of Sultan Bahoo - considered as one of basic sources of Punjabi literature - have been part and parcel of people's life for centuries in South Asia. By analysing the impact of such Sufi literature on South Asian societies, the paper argues that such literature can be an effective tool for bringing harmony across societies and the world at large through harmonization with divine morality and self-awareness. Sufi meditation arguably contains the potential to transform an individual and generate positive forces by countering the negative inclinations and evils, thereby also assisting with conflict resolution in not just individual but societal level as well.
\end{abstract}

Keywords - Sufi Literature, Peace, Harmony, Conflict Resolution, Sultan Bahoo

\section{INTRODUCTION}

Sufism has played a great role in shaping literature for centuries and it is also linked with marvelous literary work of Islam in golden age, which last from the eighth to thirteenth century [1]. In 1000 A.D, Sufi literature started to surface. Then for centuries, this literature flourished and encompassed

Sahibzada Sultan Ahmed Ali, Chairman, MUSLIM Institute, Islamabad Pakistan. variety of fields which could be found in form of mystical tales, anecdotes, manuals, metaphysics, treatises on Islamic theology, philosophy, and mystical poetry. Sufi manuals were compiled for the beginners. They served as code of conduct and lighthouse for their apt behaviors and practices. The disciples were also taught for strong relation to their mentor for keen focus on meditation and also with piety and devotion towards God. In these manuscripts, Ibn 'Arabī's (d. 1240) 'Journey to the Lord of Power' is very famous which is a handbook on spiritual purification. Some of the Sufi used tales and anecdotes for their expression. These master pieces of literature are meant as "teaching tales," the purpose of these tales and anecdotes were to infuse the disciples with a moral or mystical point. These tales are also allegorical in their content. The most famous amongst them are 'Atțār's (d. 1221) 'Conference of the Birds', Sa'di's (d. 1291) 'The Rose Garden', and many others by Persian and Arabic authors.

The philosophical writings on the nature and essence of Sufism and Islamic theology were written by the famous Sufi philosopher Abū Hāmid Imam Al-Ghazālī (d. 1111). The classic examples of such works include 'Reconstruction of Religious Sciences' and 'Alchemy of Happiness'.

Sufi poetry is another field in which Sufi poets contributed tremendously. This poetry was recited not only by disciples but also by common people especially the illiterates. Sufi poetry in the "classical era" was written by Arabic poet Ibn-alFarid (d. 1234), and also by Persian poets such as Rumi (d. 1273), Sa'di, Hāâez (d. 1390) and Jāmī (d. 1492). Mevlana Rumi is best known in the West for his monumental poetic works including Mathnawī- $\bar{\imath}$ ma'nawì and Dīwān-ì Shams-ī Tabrīzì. Rumi wrote approximately 70,000 verses of fabulous poetry in Persian language. Rumi's message was so universal that the bestselling poet of America in 2006 was not Dickinson, Whitman, Emerson or Frost but Mevlana Rumi, who was born in Central Asian region, on the borders of the Persian Empire (Iran).

As Chittick [2] explains the beauty of Sufi poetry in the following words: -

"Characteristics of Sufism are beauty, love, poetry, and music which illustrate the dimension of divine beauty and mercy. When Gibb writes - the aesthetic element in Sufism plays a part, which can hardly be overemphasized in its later expression, he is pointing to the appreciation of beauty and love that is the hallmark of the Sufi tradition......Poetic license 
allows the Sufi poets to convey the experience of God's presence with imagery that shocks the conventionally pious and flies in the face of juridical and theological discourse. In the best examples, such as those in Ibn al-Farid in Arabic, Attar, Rumi, and Hafiz in Persian and Yunus Emre in Turkish, simply hearing the poetry - especially when well recited or sung - gives rise to marvelous joy".

Seventeenth century witnessed the rise of another great Sufi Sultan-ul-Ārifeen Sultan Bahoo (1691) from the land of Punjab in South Asia who gathered general acceptance in masses in a very short period of time. His message is universal and every verse of his poetry and each sentence of his writing appeals to mind and resonate in hearts [3]. Sultan Bahoo's Punjabi and Persian work is the most satisfying blending in the world of Islamic literature, teachings and mystical poetry. His poetry permeated in remote areas of Indian sub-continent during Mughal period and was equally famous among followers of all religions. The verses of his poetry were momentous in mysticism and also replete with spiritual message that whosoever came in contact with, was galvanized into magnetic attachment. Although there were many poetic expressions of Arabic and Persian origin, but the Punjabi poems of Sultan Bahoo (Abyāt-e-Bahoo) contain deep fervours of passionate presentation of divine love [4]. Hadrat Sultan Bahoo's work is written in a style and substance peculiar to his mystic philosophy [5].

Sufi Literature promotes peace and harmony in the world as Baba Bulleh Shah (d. 1757) points out in his poetry that it is much greater sin to break the heart of any person than to tead down the temple or mosque. Sufi psychology promotoes growth, balance and harmony and has greater flexibility to fit into various cultures and societies in varied forms [6]. The heart is considered as pearl and focal point of universe by sufi poets. As Gill [7] argues if we listen to teachings of these Sufi saints and scholars, the world would become a peaceful place. The land of Punjab is already blessed with enriched Sufi literature and peotry conveying the universal message of love and respect for humanity. Sufi mystics and leaders have received widespread acceptanance in United States and Europe for their influential teachings of harmony and peace and many converts have expressed great satisfication with these teachings [8], [9].

However, in contemporary education, the holistic and integradated view of body, soul and mind has been neglected which have induced rising social issues and problems such as suicides, frustration, drug addiction among youth, excessive consumerism and commercialism, eorkplace evils and pollution and environmental degradation. Ayzi [10] points out that Sufi teachings have such potential to fill this rising gap between materialistic and spirtualisitc view of the world as it promotes self-creativity by extracting innate endowed knowledge contained in one's heart and soul rather than merely relyiing on acquired knowledge.

In this paper impact of Sufi literature on the masses has been analysed in perspective of globalisation. Firstly, it discusses the history of influence of great Sufi's literature across the globe. Secondly it discusses the essence of Sufi literature and its potential to effect huge number of people. Thirdly, it discusses the role of Sufi literature in evolving positive forces in an individual and its impact on societies. Fourthly the meditation practices of renowned Sufi saints have been discussed with respect to contemporary challenges of world peace, harmony, and conflict resolution. Lastly, workplace spirituality has been discussed in the context of harmony in the world.

In contemporary era, information is wide spread and more accessible to any individual. Same goes true with the literature. Globalization has huge impact on thinking across the regions which is redefining the understanding of culture, politics, and literature. Countries in the world are becoming increasingly diverse and would be continuing on this path in the foreseeable future. In the twenty-first century, when diverse cultures are interfacing each other and we are faced by a wide range of different perspectives. Therefore, we have to take a global perspective on a variety of economic, social political, and intellectual issues.

In the age of globalization, Sufi literature in not limited to a specific nation or region. Sufi's poetic philosophy portrays a deep-rooted culture of a society. Sufi literature addresses evil aspects of society and highlights an ideal moral value which is the essence of Sufism. Allama Iqbal (d. 1238) and Mevlana Rumi's poetry which attracted global recognition for the noble causes of self-actualization, liberty, socio-political transformation and harmony, are noteworthy [11].

Sufi literature transformed the lives of millions of people across the globe and their influence on other regions is also notable. In the nineteenth century one can observe influence of Sufi poetry on American writers Thoreau and Emerson. Sufi poets held a prominent position in influencing the course of Whitman's poetry, also in his philosophy to its structural organization. Mevlana Rumi's effect on Whitman could be easily observed [12]. In the same way Sufi poet of $20^{\text {th }}$ century Allama Iqbal has its influence across the regions. Muhammad Iqbal`s Legacy has a planetary dimension, as it belongs not only to Pakistan and Muslim world but to all humanity around the world [13].

The Sufi literature has the potential of imaginary which is in the form of Ishq-i Haqiqi (divine love). This imaginary has distinct ontology, epistemology and cosmology which needs to be understood within its own discourse and praxis. It can infuse the social world with universal meanings of love, divinity and brotherhood. This can then help us to question, contest the polluted workplace and restructure our relationships with each other and this universe. The imaginary of Ishq-i Haqiqi can also transform organizational realities especially with relevance to their purpose and mission and can cure the moral degradation of the workplace [14], [15]. The existing moral standards at individual, organizational and societal level are based on materialistic approach and devoid of any spiritual goals. Endless race of materialistic pursuit 
results in disharmoney.

Sufi theory provides a map of the cosmos that allows people to understand their situation in relation to God. It explains both what human beings are, and what they should aspire to be. It sets down a practice that can lead people from their actual situation to the final goal of human life, or from imperfection to perfection [2]. There is need to resort to the spiritual teachings of Sufis whose essential belief and philosophy is love of god, with emphasis on love and respect for all divine creation and also not to hurt anything or anyone. The Sufi literature is distinguished by its attributes of belief in love, truth and beauty [16]. He further explains that when one comes out of this materalistic approach he can dive deep into himself; this practice makes him able to be united with whole of the life and with all souls. This deep dive inside his ownself reflects in th form of harmony, beauty, peace. Sultan Bahoo invites for this inward march in beautiful words

"Heart is deeper than rivers and oceans who can fathom Heart- Hoo,

Seamen, boats and oars all are inside ocean of Heart- Hoo,

All the fourteen Realms (Spheres) are open in Heart like a tent- Hoo,

Those who fathom Heart Bahoo, are the ones who recognize Lord- Hoo".

Sultan Bahoo emphasizes on the study of man's true-self in order to nurture love and peace in mankind. Sultan Bahoo urges that one should also discover its inner-self, purify, beautify and strengthen its spirit besides strengthening, educating, purifying and beautifying physical body.

"Blackened face is better than darkened heart so that people recognise Hoo.

When face blackened and heart is fine such heart beloved recognise Hoo" [5].

This is the most profound thought that mystics have promoted in their teachings and literature. There is dire need for promoting this thought in the contemporary world [17]

\section{INTRODUCTION TO SULTAN BAHOO}

Sultan Bahoo was born in 1629 AD in the area of Shorkot, Jhang-Pakistan. His father died in his childhood, therefore his pious mother look after him. His mother herself was a Sufi and in her maternal care with spiritual tutelage resulted in his higher echelons of transcendence. She saw him undergoing through ecstatic phase, she named him Bahoo, $B a$, means 'with' and Hoo is for Allah Almighty. When Sultan Bahoo started the quest to seek 'mürshid' a perfect guide to achieve the divine pleasure, he visited various shrines to quench his thirst. On the intuitional instructions of Shaykh Abdul Qādir Gīlānī (d. 1166), he made the pledge at the hands of Syed Peer Abdul Rāhmān Dehlvi; a Qãdiri spiritual mentor in Delhi [18]. Sultan Bahoo visited many shrines and became familiar with the 'Aloom-Ahle-Qaboor'-the knowledge related to the saint in their graves [5].

Sultan Bahoo authored more than one hundred and forty books (140) in the Persian language on mystical knowledge.
$\mathrm{He}$ is famous in the Indo-Pak sub-continent for his Punjabi poetry 'Abyāt-e-Bahoo'. There is an ecstasy of love in his poetry, that people repeat vocally, and verbally - 'Hoo' in unison with heart and soul constantly developing every breath in contemplation of Him - Hoo. He says that the soul merges in Essence of the Lord then one deserves the name 'Bahoo'. Being a 'Fanah-Fillah' mergence in Essence he was bestowed with the power to embellish the souls from a king to a common man [19].

When one reads the books of Sultan Bahoo, he eventually gets drawn into the world of true knowledge; the knowledge which encompasses oneself, and it nurtures inner-self just like outer-self is nurtured by the intake of food. Sultan Bahoo's knowledge is like a deep ocean where one has to dive deep to reach at great pearls that are hidden deep beneath the surface [20]. The core message of Sultan Bahoo is reaching the heights of humanity through revolution and this revolution is not riot, instead it is transformation of heart towards peace and eternal love for the God and His beloved Prophet ( $\square$ ).

Sultan Bahoo remains one of the prominent Sufi mystics of Indo-Pak sub-continent whose impact could be felt across the world. Although Sultan Bahoo authored around 140 books in Persian yet he remains famous for his Punjabi poetical work. The attraction of these Abyāt is so strong that these became worldwide renowned with Sultan Bahoo's name [5]. Every single verse of Abyāt describes the deep philosophy and meaning which reveal itself upon the reader and listener. These Abyāt played a vital role in character building of youth. Popular among the folks, Abyāt became part and parcel of their lives leaving deep impact on culture and traditions [21]. He has presented such strong concepts in very easy way that even modern-day scholars name the translations of Abyāt of these concepts like 'Death Before Dying' [22] and 'Heart Deeper than Ocean' [5].

All the Punjabi poetry of Sultan Bahoo ends on 'Hoo'. Meditational impact of Sultan Bahoo's Abyāt is evident from the concept of 'Hoo'. Hoo has always been considered by Sufis as the excellence of the status of 'Zat', the Almighty [23]. Sufis describe the actual name of Allah Almighty in four stages As the Ayat-al-Kursi describes in AlQur'ān,

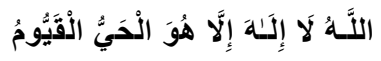

The last part of Surah AlHashr in Al- Qur'ān reads,

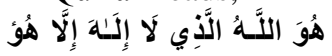

The rhythm and rhyme of Hoo made his poetry popular among people. Musicians started presenting it with music which further enhanced its impact and recognition. The translator of 'Death before dying' describes this reality when he acknowledges his mother for introducing him with Punjabi lyrics and Ustad Pathana Khan with Sultan Bahoo [22]. In this way his poetry became part of entertainment events as well. As Böwering notes in Foreword [19],

"His poetry was so close to the hearts and minds of the Punjabi people that it only needed oral tradition to be divulged at first and favoured being augmented over time by imitation. 
Sung at village gatherings and in town halls, it was embraced by the young and became especially dear to the villagers who could not read and write. Men would sit together for hours, joining in the refrain, and women would listen in from behind curtains and veils."

\section{THE CONCEPT OF SUFI MEDITATION IN SUFI LITERATURE}

We are witnessing intercultural communication with its great achievements in technology. It is also an age of devasting existential crisis where the visions of a new orientation of man and society are illusory. There is need of spiritual intervention in human affairs which is indispensable to put an end to dehumanization to restore the worth and dignity of human being.

The meditation in Islam is aimed at purification of heart from all the evils and bad deeds. Sufi literature encourages us to achieve 'inner awakening', mindfulness and purification of self so that an individual can utilize his abilities for higher purpose of living and creating peace for himself and others. According to famous Hadìth-e-Gabrā'̂̀l, Exalted Prophet Mohammad ( $\square$ ) also teaches us how to do meditation which is sometimes called Ihsan,

"Ihsan is to worship Allah ( $\square$ ) as if you see Him, and if you do not achieve this state of devotion, then (take it for granted that) Allah $(\square)$ sees you." (Sahi-ul-Bakhari, Vol 1, Book 2, Hạīith 43).

Chittick [2] describes,

"Those who spoke for the branch of 'ihsan' maintained that 'Islam' and 'iman' must be subordinated to the highest goal, which is 'to worship God as if you see him.' By and large such people were associated with what has come to be known as 'Sufism'... Ghazali illustrated in copious detail how 'Islam' and 'iman' need to be vivified and validated by 'ihsan'."

This is the ultimate purpose of any Sufi meditation or prayer to achieve highest level of 'inner consciousness' which brings purification of heart and soul and frees the self from all the evils. The aim of such meditation is not only to cultivate higher purpose of living in an individual but also make him God-fearing rather God-loving before making any decisions of life and promotes leadership qualities such as selfintrospection and self-accountability which promotes spirituality not only at work but also in other matters of life. Allah Almighty ( $\square$ ) emphasizes on achieving purity of self in the following verse of Holy Qur'ān,

"Consider the human self, and how it is formed in accordance with what it is meant to be, and how it is imbued (filled) with moral failings as well as with consciousness of God! To a happy state shall indeed attain he who causes this [self] to grow in purity, and truly lost is he who buries it [in darkness]". (Qur'ān 91:7-10)

The inner purification is based on the concept of immersion and unison with Allah ( $\square$ ) which frees a divine seeker from worldly desires and he achieves self-actualization through divine intimacy. The important aspect in Sufi meditation is the remembrance (dhikr) of Allah Almighty ( $\square$ ). The excessive dhikr creates numerous impacts on one's inner as well as outer self with the divine blessings. As Sultan Bahoo says in his verses [19],

"Annihilate (immerse and unify) your body in Allah ( $\square$ )'s Actual-Name so that you attain eternal life."

Acquiring all these states depends upon contemplation of Actual-Name of Allah ( $\square$ ) with imagination. This aspect is also stated in Exalted Qur'ān in the following verses,

"So is one whose chest Allah ( $\square$ ) has expanded to Islam (through dhikr/meditation) and he is upon a light from his Lord [like one whose heart rejects it]? Then woe to those whose hearts are hardened against the remembrance (meditation) of Allah ( $\square$ ). Those are in manifest error." (Qur'ān 39:22)

Hadrat Sultan Bahoo explains that the remembrance of Allah ( $\square$ ) brings changes in one's inner-self. He says in his famous Abyāt-e-Bahoo [5],

"Spiritual mentor planted the "Jasmine" sapling of Allah's name in my heart - Hoo,

Irrigated with water of negation and affirmation in whole body - Hoo,

It has blossomed and emit sweet fragrance all within - Hoo,

Long live my perfect guide, Bahoo, who planted it in me Hoo."

Thus the inner peace and satisfaction in one's heart is achieved by dhikr and contemplation of Allah Almighty ( $\square$ ). Sufi meditation enhances positive forces in one's inner-self and thus brings peace within and without. To create peaceful society Sufi meditation through remembrance of Allah Almighty ( $\square$ ) can play a vital role as it eradicates the evils from body such as lust, disrespect, corruption and anger. Evils like Islamophobia, Xenophobia and racism can be eradicated through Sufi practices and using Sufi literature as a tool to achieve this goal.

Workplace spirituality is another aspect - getting much importance over the globe especially in the corporate sector which has much relevance to Sufi meditation. To create spiritual individual workplace or society Sufism is as an alternative to spiritually impoverished and materialistic modernity which is based on temporary material goals. Sufi meditation can serve as a cure to materialism's negative impacts on the individual as well as religious communities [24].

Greed is the main cause of today's social and economic problems such as starvation, poverty, lack of water, corruption and moral and ethical issue. In order to curb such evil behaviors, Sufi meditation practices are very effective which cultivate inner consciousness through divine recognition and also promote attitude of caring and altruism. Hadrat Sultan Bahoo describes that if one looks to overcome the evil desires and wishes to live the life with positive force, then the meditation can help him out as it creates following abilities [5]:-

"If rubbish thrown at you then endure it - Hoo,

If someone abuses or shouts at you, be polite to him - Hoo,

Tolerate noise, taunts, insult and humiliation for the sake of 
Friend - Hoo,

The most Powerful holds our reins Bahoo, live as He makes you live - Hoo."

Imam Al Ghazali [25] describes:

"If he follows sexual passion and greed, he acquires the evils for impurity, shamelessness, meanness, miserliness, hatred and other bad habits, if he obeys the dictates of anger, he acquires heinous conducts such as haughtiness, pride, love of power, self-praise, jokes, contempt for others, oppression. If he obeys the devil, he obeys evil conducts such as deceit, deception, treachery, fraud etc. When he controls the above evils, he is endowed with divine qualities such as wisdom, knowledge, certain faith, knowledge of nature of all things. When he becomes free from sexual passion and anger, he acquires the following virtues-pardon, contentment, selfsatisfaction, ascetism, piety, God fear, contentment and shame. If he keeps anger under control, he gains heroism, kindness, patience, silence etc."

Such meditation practices could be beneficial for enhancing not only workplace spirituality at organization level but also at country and global level to reduce extremism and promote love and respect of humanity which is the core element of Sufi teachings and meditation practices to promote tolerance, divine love, greater sense of responsibility and accountability. Thus Sufi literature drives its relevance in corporate sector due to its universal appeal.

\section{Sultan Bahoo's Literature Of Peace ANd Harmony}

Sultan Bahoo's message is not confined to any segment of society but to mankind at large, in his prose and poetry topic of discusions are Faqr, meditation, austerity, self-actualization and likewise which directly relates to an individual regardless of his cast, religion and ethnicity. Sultan Bahoo invites to take the holistic view of this world. Because temporary materail goals such as lust of power and wealth always lead towards dissarray and conflicts.

A major problem of our time is that life has become ostensible and people want to display their wealth. Therefore, they want to become rich at any cost knowing the fact they are deceiving themselves. Similarly, nations want superiority over other nations even if they have to exploit other countries. Sultan Bahoo warns about this attitude which would lead to devastation for entire humanity.

"Self-conceit is extreme heresy; if you are not going to pay attention now, you will be embarrassed in the presence of eighteen thousand universes on the Day of Judgement, you will be humiliated and ashamed". [19]

Sultan Bahoo is of the opinion that human heart is endowed with such power that it can do self accountability. One who practices meditation is very sensetive towards his behaviour towards people and socities. Because this practice enables him to judge his each action or speech for any harmful impact.

"Judges (according to Islamic-Divine-law) are of two types: first is for exterior (world) and the second one is for innermost.
Within a human, base-self and spirit are like claimant and defendant in their own rights. The Judge who gives fair judgement on the case (of base-self and spirit) processes virtues of soul and is righteous, and just due to the grace of Allah Almighty ( $\square$ ). The verdict of the judgement is that the tormentor base-self is to be executed and the real spirit is to be reinstated (that is in union with Divine-Truth). Therefore, every limb of the body's kingdom becomes the palace of peace" [19].

Sultan Bahoo expresses in his famous Abyāt

"Searched closer to jugular vein Bahoo, all conflicts came to an end - Hoo".

Sultan Bahoo is of the opinion if every member of a society recognizes the divine reality being the near most to the core of a human being, most of the social, racial, linguistic, regional and societal issues will come to an end. With such selfconsciousness, false sense of vanity, pride and superiority will be eradicated from the societies at national and international level. Egoistic approach of human beings is root cause of every cultural, social and regional conflict. Sultan Bahoo's concept of self-recognition is key to eliminate these clashes and conflicts. When every human discovers single reality of soul, inner confrontation reduces and beam of harmony and reconciliation emanates from him. Such strong was the message of Sufis that the diverse society like in South Asia remained in social peace and harmony for centuries. As [26] note about the history of Sufis in Indo-Pak subcontinent by providing the example of Bangladesh,

"The spiritual power and noble character of the Sufis won the hearts of the local people. Actually, the khanqahs of the Sufis were the centres of reconciliation of Hindus and Muslims."

Concept of Perfect Mentor is also essential component of teachings of Sultan Bahoo. He expresses in his poetry that Mentor enriches inner self of a disciple with the light of Oneness of Allah and guides him regarding self-recognition. Role of Mentor is essential if a disciple wants to achieve essence of spirituality. He is initially purged by Mentor of evil thoughts of pride, hate, vanity and lust of world. Consequently, he ascertains his reality of inner-self and piety and peace encircle him. He is no more antagonistic to the other human beings. Consequently, society becomes hub of peace, love and brotherhood [5].

"He lives very close yet seems far away, He doesn't enter the courtyard - Hoo,

Unable to find Him internally ill-fated ones pursue Him outwardly - Hoo,

Nothing is achieved by travelling far, within the house (self) the objective is gained - Hoo,

Purify the heart like a mirror Bahoo, all veils will be removed - Hoo".

\section{CONCLUSION}

The Sufi literature has important implications for fostering world peace and harmony because it is aimed at curbing 
individual and social evils by connecting oneself to the divine reality and inner purification through spiritual mindful meditation practices under the inspiration and guidance of charismatic organizational leader. In this regard, the teachings of Faqr (spiritual excellence) as proliferated by Sultan Bahoo in his Abyāt (couplets) and valuable books on mystical teachings, in the light of Quran and Hadith, are very crucial for developing inner consciousness, purification of heart and soul and achieving the higher purpose of life through divine recognition and intimation.

Sufi spiritual teachings have great universal appeal for addressing the contemporary issues of workplace spirituality, corporate social responsibility, workforce diversity, ethnic and religious harmony, environmental sustainability and world peace. Sufi literature has also promoted the concept of metaphysics to inculcate the beautiful blend of spirituality and science to better understand the universe and it has been included in the curriculum of top-ranked universities of the world for character-building and principle-centered leadership which not only cater to the business and economic needs of the world but also promote the sense of societal and environmental responsibility by promoting self-actualization, selfintrospection and sensible leadership to create harmony at organizational, societal, country and international level.

\section{REFERENCES}

[1] M. Specia, The New york Times, 2017, Retrieved from https://www.nytimes.com/2017/11/24/world/middleeast/sufi-muslimexplainer.html

[2] W. C. Chittick, Sufism: A Short Introduction, In W. C. Chittick, Sufism: A Short Introduction. London: One world Press, 2007.

[3] N. A. Nomani, The general acceptance and spiritual inspiration of Sultan Bahu poetry, The Islamic culture, 2019.

[4] T. Anjum, Bridal Symbolism in Sultan Bahoo's Poetry, 2013. Retrieved from www.sultanbahoo.net

[5] S. Bahoo, Heart Deeper than Ocean, Z. A. Awan Trans., Lahore: AlArifeen Publications, 2017.

[6] R. Frager, Heart, self, \& soul: The Sufi psychology of growth, balance, and harmony, Quest Books, 2013, Retrieved from https://books.google.com.hk/books?hl=en\&lr=\&id=mlVbBgAAQBAJ\& oi=fnd \&pg=PR9\&dq=Sufi+literature+and+harmony\&ots=C7yR3VuF6 P\&sig=CQxACzw2Y711kE-nJZSMgvGW-

$4 \&$ redir_esc $=\mathrm{y} \# \mathrm{v}=$ onepage $\& \mathrm{q}=$ Sufi $\% 20$ literature $\% 20$ and $\% 20$ harmony $\& \mathrm{f}=$ false

[7] S. Gill, "International conference on Sufism," Pakistan Academy of Letters, Islamabad.

[8] R. Acim. (2018). The Reception of Sufism in the West: The Mystical Experiences of American and European Converts, Journal of Muslim Minority Affairs, 38(1), pp. 57-72.

https://doi.org/10.1080/13602004.2018.1432145

[9] S. Schwartz, The other Islam: Sufism and the road to global harmony. Harmony, 2008. Retrieved from https://books.google.com.hk/books?hl=en\&lr=\&id=S_U-

S9cgKGIC\&oi=fnd\&pg=PA1\&dq=Sufi+literature+and+harmony\&ots= LVZQCDutr7\&sig=BS8pZIWVAE39ZSbUUdkjgScZ0Pg\&redir_esc=y $\# \mathrm{v}=$ onepage \&q=Sufi $\% 20$ literature $\% 20$ and $\% 20$ harmony $\& \mathrm{f}=$ false.

[10] M. Ayazi, Islamic Sufism and Education for Peace. Edward J. Brantmeier vd (ed.), Spirituality, Religion and Peace Education, Charlotte, NC: Information Age Publishing, 19-35, 2010.

[11] C. A. Kafka, Washington post, 2019. Retrieved from Washington post: https://www.washingtonpost.com/entertainment/books/rumi-americasfavortie-poet-from-persia-with-love/2017/01/17/240ccc82-d77f-11e69f9f-5cdb4b7f8dd7_story.html
[12] B. Moghaddas, The Influence of Rumi's Thought on Whitman's Poetry, Theoretical and Applied Linguistics Series, 2015.

[13] MUSLIM Institute, 2019. Retrieved from https://musliminstitute.org/PublicationDetail?publication=165/Day-Three-Report-of-3Day-International-Allama-Muhammad-Iqbal-Conference

[14] S. U.-H. Khan, A Sufi View of Human Transformation and Its Organizational Implications. In S. U.-H. Khan, Handbook of Personal and Organizational Transformation, 2018, pp. 833-865. https://doi.org/10.1007/978-3-319-66893-2_45

[15] U. Hasan, Workplace Spirituality and Training Method of Founding Father of Islahee Jamaat, Lahore: Mirrat ul Arifeen International, 2017.

[16] P. Smith, Three great Abbasid Sufi Poets, In P. Smith, Three great Abbasid Sufi Poets, Victoria: New Humanity Books, 2015, p. 46.

[17] M. D. Awan. (2016). Hadhrat Sultan Bahoo's Proposed Human Society. MUSLIM PERSPECTIVES Journal, I(2), pp. 60-78.

[18] M. I. M. Garcia. (2017). Channels of Knowledge Transfer of Sultan Bahoo's Teachings in Modern Era, MUSLIM PERSPECTIVES Journal, vol. II(3), pp. 62-89.

[19] S. Bahoo, Nūr-ul-Hudā. Tr. by M.A. Khan. Lahore: Arifeen Publications, 2019.

[20] T. Sarwar, Sultan Bahoo, 2011. Retrieved from https://www.sultanbahoo.net/blog/transforming-message-from-theteachings-of-hazrat-sakhi-sultan-bahoo-ra/

[21] Z. A. Awan, Sultan Bahoo: A Living Legacy, Lahore: Al-Arifeen Publications, 2019.

[22] J. J. Elias, ed. Death before Dying. The Sufi Poems of Sultan Bahoo, London: University of California Press, 1998.

[23] M. A. Rahbeen, Comparative Study of Hadrat Sultan Bahoo. in International Hadrat Sultan Bahoo Conference,. Islamabad: MUSLIM Institute, 2013.

[24] J. Hammer, The Soul of Islam: Writing and Publishing as engaged Sufi . Journal for Islamic Studies, 2006, pp. 36-70.

[25] A. H. M. Al-Ghazali, Revival of Religious Learnings (Ihyallum-Id-Din). vol. 3, tr. by Fazlul Karim. Karachi: Darul Ishaat, 1993.

[26] Abdullah Al Masud, Abdullah Md Faruk, and Md Ruhul Amin. (2017). The Contributions of Sufism in Promoting Religious Harmony in Bangladesh. Jurnal Usuluddin 45(2),: 105-122. https://doi.org/10.22452/usuluddin.vol45no2.5

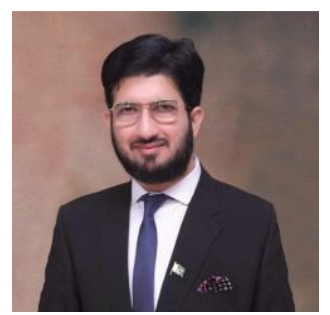

Sahibzada Sultan Ahmed Ali is Chairman of the research based think-tank MUSLIM Institute, Chairman Advisory Board of MUSLIM PERSPECTIVES Journal, Chief Editor of monthly magazine Mirrat-ulĀrifeen International, Chairman of AlĀrifeen Group of Publications \& AlĀrifeen Digital Production. He is from the tenth line among the descendent of Hadrat Sultan Bahoo, an eminent Sufi Saint of the sub-continent. He has visited different countries representing Institute and Pakistan; to participate in many high level official meetings and programs. He has delivered lectures and presented papers at many national and international think-tanks, universities, academic institutions and many other forums. He has also published many articles and papers. Being the Chairman of MUSLIM Institute he has organized and supervised many international programmes and activities. 